\title{
RELATIONSHIP BETWEEN CLIMATIC CONDITION AND MANGROVE FOREST STRUCTURE ON NORTHERN COAST OF VIETNAM
}

\author{
Pham Hong Tinh ${ }^{1}$, Nguyen Thi Hong Hanh ${ }^{2, *}$, Mai Sy Tuan ${ }^{3}$ \\ ${ }^{I}$ General Department of Land Administration, No. 78/9 Giai Phong, Dong Da, Hanoi, Vietnam \\ ${ }^{2}$ Hanoi University of Natural Resources and Environment, No. 41A Phu Dien, Bac Tu Liem, \\ Hanoi, Vietnam \\ ${ }^{3}$ Hanoi National University of Education, No. 136 Xuan Thuy, Cau Giay, Hanoi, Vietnam \\ "Email: honghanhsp@yahoo.com
}

Received: 23 November 2015; Accepted for publication: 11 January 2016

\begin{abstract}
The differences in mangrove forest structure, climate, and the linear relationship between climate and mangrove forest structure on the northern coast of Vietnam were analyzed using mangrove forest data measured in 28 sample plots (Dong Rui-8, Xuan Thuy National Park-12 and Lach Sung-8) and climate data collected at the meteorological stations near the study sites (Dong Rui-Tien Yen station, Xuan Thuy National Park-Van Ly station and Lach Sung-Thanh Hoa station) in the period of 1994 - 2012. Results showed that the differences in mangrove forest structure (stem diameter, biomass and basal area) and climate (temperature and rainfall) among study sites were significant ( $\mathrm{p}$ < 0.05). Stem diameter, tree height, basal area and biomass had positive linear relationship with annual average temperature and January average temperature, and negative linear relationship with annual rainfall. A consistently low regression coefficient of less than 0.66 was found among the variables. However, all the regression models were statistically significant $(\mathrm{p}<0.05)$. The results could be used to develop multiple linear regression models to predict the change of mangrove ecosystems.
\end{abstract}

Keywords: climate, mangroves, northern coast of Vietnam.

\section{INTRODUCTION}

Northern coast of Vietnam stretches across the provinces of Quang Ninh, Hai Phong, Thai Binh, Nam Dinh, Ninh Binh and Thanh Hoa, and is divided, according to the distribution and characteristics of mangrove ecosystems, into two zones: I) North-east coast from Ngoc cape to Do Son cape; II) Northern delta from Do Son cape to Lach Truong estuary. Due to the differences in topography, climate and hydrology, ecological characteristics of mangrove ecosystem in these zones are also different $[1,2]$.

Mangrove ecosystem on the northern coast of Vietnam plays important roles in economic development and environmental protection. Mangrove ecosystem supports a veriety of economic 
activities, such as firewood, charcoal, shrimp, crabs, etc. collection. Mangrove ecosystem stabilizes coastlines, promote coastal accretion and provide a natural barrier against storms and tidal bores. In addition, mangrove forest is a carbon sink accumulating atmospheric $\mathrm{CO}_{2}$, contributing to reduction of greenhouse gas emission $[1,2,3,4,5,6]$.

According to Ministry of Natural Resources and Environment (2012) [7], Vietnam will be one of the countries most affected by climate change. The change in temperature, rainfall will impact directly to the structure, growth and development of coastal ecosystems, including mangrove forests $[2,5]$. Therefore, studying and modeling the relationship between mangrove structure, growth of mangrove forest and climate are essential and could be used to predict the variation of mangrove ecosystems in the context of climate change.

In this paper, we present the initial results of study on the relationship between climate and mangrove forest structure (tree height, stem diameter at $0.3 \mathrm{~m}$ height, basal area and biomass) conditions (temperature and rainfall) on northern coast of Vietnam.

\section{MATERIALS AND METHODS}

\subsection{Study site}

Three study sites, which have specific mangrove ecosystems, high biodiversity and the least affected by human, were selected to establish sample plots for measuring the structural characteristics of the vegetation and climate. The selected sites are: 1) Dong Rui (Tien Yen, Quang Ninh), 2) Xuan Thuy national park (Giao Thuy, Nam Dinh) and 3) Lach Sung esturary (Thanh Hoa) (Figure 1).

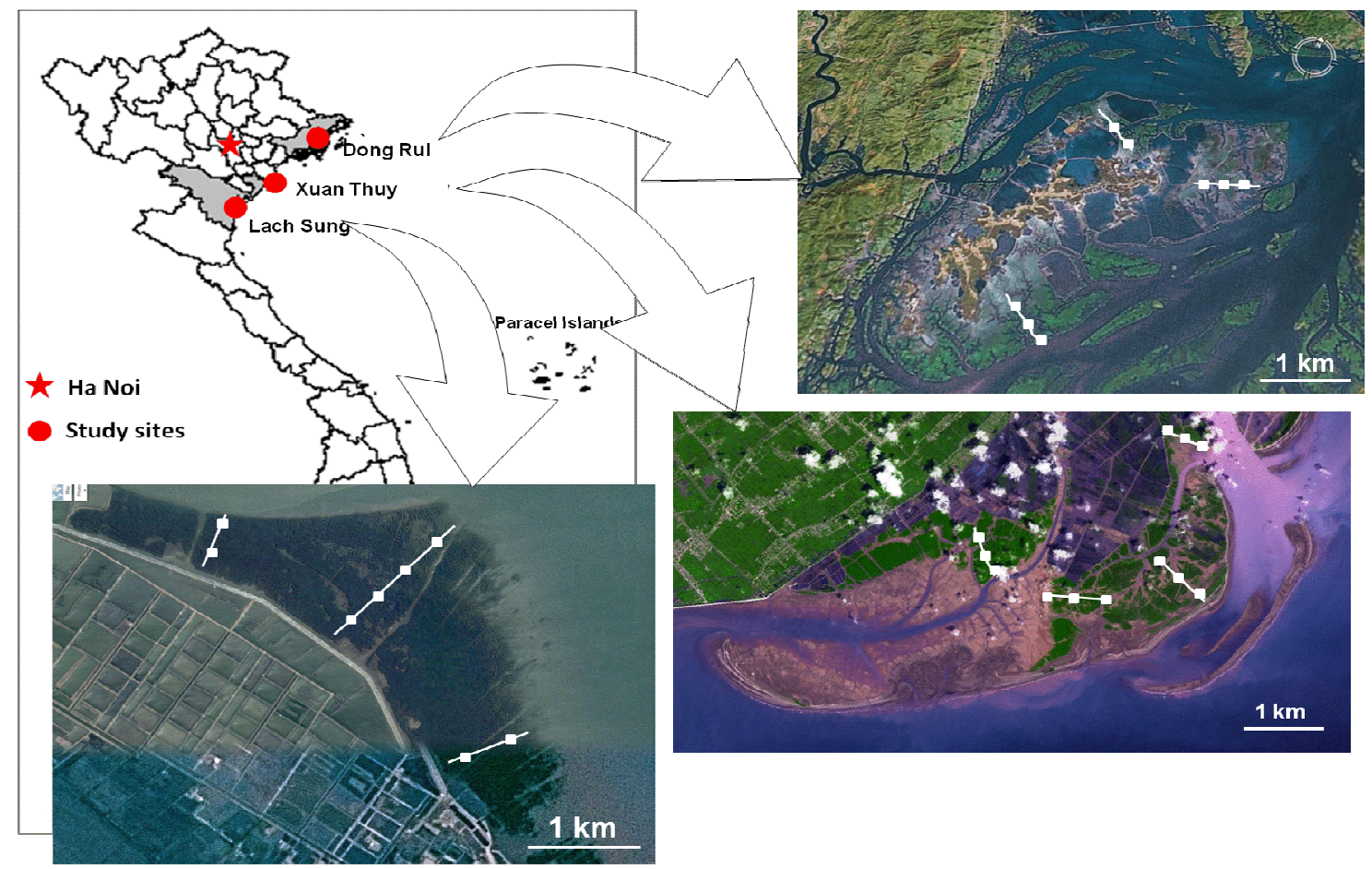

Figure 1. Location of study sites. 


\subsection{Data collection}

\subsubsection{Mangrove forest structure}

Mangrove forest structure (tree height, diameter at $0.3 \mathrm{~m}$ height, basal area, and biomass) were measured in the $10 \times 10 \mathrm{~m}$ sample plots established in the study sites. In 3 study sites, we established 28 sample plots (8 in Dong Rui, 12 in Xuan Thuy national park and 8 in Lach Sung estuary). In each sample plot, species name, tree height, diameter at $0.3 \mathrm{~m}$ height of all trees were measured and recorded. We measured the data on mangrove forest structure in Dong Rui on 5-8 April 2014, in Xuan Thuy on 1-4 May 2014 and in Hau Loc on 5-7 May 2014. The sample plots were established by the method of Nguyen Nghia Thin (2008) [8].

Tree height was measured directly by a pole $(0.1 \mathrm{~m}$ scale). Stem circumference at $0.3 \mathrm{~m}$ height was measured by measuring tape and then converted into stem diameter. Tree height and stem diameter for each sample plot were calculated by total tree height, stem diameter of all trees dividing the total number of trees in the sample plot. The tree height and stem diameter for a study site were average tree height and stem diameter of all sample plots measured in that study site.

Basal area $\left(\mathrm{m}^{2} / \mathrm{ha}\right)$ for each sample plot was calculated by the total cross section area of all trees in the sample plot dividing the area of the sample plot. Basal area for a study site was average basal area of all sample plots measured in that study site.

The common biomass equation $B=0.251 \rho D^{2,46}$ [9] was used to calculate the biomass of each tree in the sample plots, in which $B$ is biomass $(\mathrm{kg}), D$ is stem diameter $(\mathrm{cm})$ and $\rho=0.752\left(\mathrm{~g} / \mathrm{cm}^{3}\right)$ is the wood density [3]. Biomass (tons/ha) of each sample plot was calculated by the total biomass of all trees in the sample plot dividing sample plot area. Biomass of a study site was average biomass of all sample plots measured in that study site.

\subsubsection{Climate condition}

Phan Nguyen Hong (1991), Nguyen Hoang Tri (1999) and Blasco (1996) [1, 5, 10] documented that the changes in temperature and rainfall are factors limiting the growth and development of mangroves. Therefore this study was conducted to specify the relationship between those climate conditions and mangrove forest structure. Climate data, including annual average temperature, annual average rainfall and average temperature of the coldest month (January), of each study site were calculated from monthly temperature, rainfall collected from Hydrometeorological Data Center (Ministry of Natural Resources and Environment). The climate data was recorded at the meteorological station near the study site in the period of 1994 2012 (Dong Rui - Tien Yen station; Xuan Thuy national park - Van Ly station and Lach Sung Thanh Hoa). The average temperature of the coldest month was also considered because low temperature is a limiting factor affecting growth and development of mangroves thus affecting their structure, species composition and distribution $[2,5,10]$.

\subsection{Statistical analysis}

Climate data and mangrove forest data were described by using statistical software SPSS 11.5 and Microsoft Excel 2007. The description of the basic features of the data is presented in Table 1. One-way analysis of variance (one-way ANOVA) was used to assess differences in mangrove forest structure and climate at different study sites. The ordinary least square method was used to 
construct the regression models, i.e. to determine the parameters $a, b$ for the equation $y=a x+b$, when $x$ is independent variable (annual average temperature, January average temperature or annual average rainfall) and $y$ is dependent variable (tree height, biomass, basal area or diameter at $0.3 \mathrm{~m}$ height). The corellation coefficient $\left(\mathrm{R}^{2}\right)$ and Fisher test (F-test) were used to evaluate the goodness of fit on data $[11,12]$.

Table 1. Descriptive statistics: variables measured at different study sites.

\begin{tabular}{|c|c|c|c|c|c|c|c|}
\hline \multirow{2}{*}{ Variables } & \multirow{2}{*}{ Study sites } & \multirow{2}{*}{$\mathrm{N}$} & \multirow{2}{*}{ Mean } & \multirow{2}{*}{$\begin{array}{l}\text { Std. } \\
\text { Dev. }\end{array}$} & \multirow{2}{*}{$\begin{array}{l}\text { Std. } \\
\text { Err. }\end{array}$} & \multicolumn{2}{|c|}{$\begin{array}{l}95 \% \text { confidence } \\
\text { intervals }\end{array}$} \\
\hline & & & & & & $\begin{array}{l}\text { Lower } \\
\text { limit }\end{array}$ & $\begin{array}{l}\text { Upper } \\
\text { limit }\end{array}$ \\
\hline \multirow{3}{*}{$\begin{array}{l}\text { Annual average } \\
\text { temperature }\left({ }^{\circ} \mathrm{C}\right)\end{array}$} & Dong Rui & 19 & 22.9 & 0.5 & 0.1 & 22.7 & 23.1 \\
\hline & Xuan Thuy & 19 & 23.7 & 0.6 & 0.1 & 23.4 & 24.0 \\
\hline & Lach Sung & 12 & 24.4 & 0.5 & 0.1 & 24.0 & 24.7 \\
\hline \multirow{3}{*}{$\begin{array}{l}\text { January average } \\
\text { temperature }\left({ }^{\circ} \mathrm{C}\right)\end{array}$} & Dong Rui & 19 & 15.3 & 1.3 & 0.3 & 14.7 & 15.9 \\
\hline & Xuan Thuy & 19 & 16.4 & 1.4 & 0.3 & 15.8 & 17.1 \\
\hline & Lach Sung & 12 & 16.8 & 1.3 & 0.4 & 16.0 & 17.7 \\
\hline \multirow{3}{*}{$\begin{array}{l}\text { Annual average } \\
\text { rainfall }(\mathrm{mm})\end{array}$} & Dong Rui & 19 & 2351 & 404 & 93 & 2156 & 2546 \\
\hline & Xuan Thuy & 18 & 1612 & 249 & 59 & 1489 & 1736 \\
\hline & Lach Sung & 12 & 1751 & 259 & 75 & 1586 & 1915 \\
\hline \multirow{3}{*}{$\begin{array}{l}\text { Diameter at } 0,3 \mathrm{~m} \\
\text { height }(\mathrm{cm})\end{array}$} & Dong Rui & 8 & 2.9 & 1.0 & 0.4 & 2.1 & 3.8 \\
\hline & Xuan Thuy & 12 & 3.1 & 0.9 & 0.3 & 2.6 & 3.7 \\
\hline & Lach Sung & 8 & 4.3 & 1.2 & 0.4 & 3.4 & 5.3 \\
\hline \multirow{3}{*}{ Tree height (m) } & Dong Rui & 8 & 2.5 & 0.7 & 0.2 & 1.9 & 3.1 \\
\hline & Xuan Thuy & 12 & 3.6 & 1.7 & 0.5 & 2.5 & 4.7 \\
\hline & Lach Sung & 8 & 3.0 & 0.4 & 0.1 & 2.7 & 3.3 \\
\hline \multirow{3}{*}{ Biomass (ton/ha) } & Dong Rui & 8 & 31.4 & 10.6 & 3.7 & 22.6 & 40.2 \\
\hline & Xuan Thuy & 12 & 44.9 & 12.6 & 3.6 & 36.9 & 52.9 \\
\hline & Lach Sung & 8 & 107.2 & 54.7 & 19.3 & 61.5 & 152.9 \\
\hline \multirow{3}{*}{ Basal area $\left(\mathrm{m}^{2} / \mathrm{ha}\right)$} & Dong Rui & 8 & 7.0 & 1.8 & 0.6 & 5.4 & 8.5 \\
\hline & Xuan Thuy & 12 & 13.0 & 7.8 & 2.3 & 8.0 & 17.9 \\
\hline & Lach Sung & 8 & 21.3 & 10.1 & 3.6 & 12.9 & 29.8 \\
\hline
\end{tabular}

\section{RESULTS AND DISCUSSIONS}

\subsection{Climatical differences among study sites}

Climatical differences among study sites were assessed by using one-way ANOVA. The results showed a significant difference in the annual average temperature, January average 
temperature and annual average rainfall among the study sites $(\mathrm{p}<0.01)$. However, the pair comparisons (Table 2) showed that January average temperatures and annual average rainfall in Xuan Thuy national park were not significantly different from January average temperatures and annual average rainfall in Lach Sung estuary $(\mathrm{p}>0.05)$. That may be due to the distance between Xuan Thuy national park and Lach Sung estuary (about $50 \mathrm{~km}$ in north-south direction) is much shorter than distance between Dong Rui and Xuan Thuy national park (about $100 \mathrm{~km}$ in north-south direction) (Figure 1), and Dong Rui is located in Tien Yen Gulf and surrounded by several small islands.

Table 2. Climatical differences among study sites.

\begin{tabular}{|l|c|c|c|}
\hline \multirow{4}{*}{ Variables } & Study sites & Differences & Significant level $(p)$ \\
\hline \multirow{3}{*}{$\begin{array}{l}\text { Annual average } \\
\text { temperature }\left({ }^{\circ} \mathrm{C}\right)\end{array}$} & Đong Rui- Xuan Thuy & -0.9 & $<0.01$ \\
\cline { 2 - 4 } & Xuan Thuy-Lach Sung & -0.6 & $<0.01$ \\
\cline { 2 - 4 } & Lach Sung-Đong Rui & 1.5 & $<0.01$ \\
\hline \multirow{3}{*}{$\begin{array}{l}\text { January average } \\
\text { temperature }\left({ }^{\circ} \mathrm{C}\right)\end{array}$} & Đong Rui- Xuan Thuy & -1.1 & $<0.05$ \\
\cline { 2 - 4 } & Xuan Thuy-Lach Sung & -0.4 & 0.404 \\
\cline { 2 - 4 } & Lach Sung-Đong Rui & 1.5 & $<0.01$ \\
\hline \multirow{3}{*}{$\begin{array}{l}\text { Annual average } \\
\text { rainfall }(\mathrm{mm})\end{array}$} & Đong Rui- Xuan Thuy & 738 & $<0.01$ \\
\cline { 2 - 4 } & Xuan Thuy-Lach Sung & -138 & 0.396 \\
\cline { 2 - 4 } & Lach Sung-Đong Rui & -600 & $<0.01$ \\
\hline
\end{tabular}

\subsection{Forest structural differences among study sites}

Table 3. Forest structural differences among study sites.

\begin{tabular}{|l|c|c|c|}
\hline \multirow{2}{*}{ Variables } & Study sites & Differences & Significant level $(p)$ \\
\hline \multirow{3}{*}{$\begin{array}{l}\text { Diameter at 0.3 } \\
\text { m height }(\mathrm{cm})\end{array}$} & Đong Rui- Xuan Thuy & -0.2 & 0.660 \\
\cline { 2 - 4 } & Xuan Thuy-Lach Sung & -1.2 & $<0.05$ \\
\cline { 2 - 4 } & Lach Sung-Đong Rui & 1.4 & $<0.05$ \\
\hline \multirow{3}{*}{ Tree height (m) } & Đong Rui- Xuan Thuy & -1.1 & 0.171 \\
\cline { 2 - 4 } & Xuan Thuy-Lach Sung & 0.6 & 0.588 \\
\cline { 2 - 4 } & Lach Sung-Đong Rui & 0.5 & 0.232 \\
\hline \multirow{2}{*}{$\begin{array}{l}\text { Biomass } \\
\text { (ton/ha) }\end{array}$} & Đong Rui- Xuan Thuy & -13.5 & $<0.05$ \\
\cline { 2 - 4 } & Xuan Thuy-Lach Sung & -62.4 & $<0.05$ \\
\hline
\end{tabular}




\begin{tabular}{|l|c|c|c|}
\hline \multirow{4}{*}{ Variables } & Study sites & Differences & Significant level $(p)$ \\
\cline { 2 - 4 } & Lach Sung-Đong Rui & 75.8 & $<0.05$ \\
\hline \multirow{3}{*}{$\begin{array}{l}\text { Basal area } \\
\left(\mathrm{m}^{2} / \mathrm{ha}\right)\end{array}$} & Đong Rui- Xuan Thuy & -6.0 & 0.092 \\
\cline { 2 - 4 } & Xuan Thuy-Lach Sung & -8.4 & $<0.05$ \\
\cline { 2 - 4 } & Lach Sung-Đong Rui & 14.4 & $<0.01$ \\
\hline
\end{tabular}

Statistical analysis (one-way ANOVA) showed that the differences in stem diameter, biomass and basal area among study sites were significant $(p<0.05)$. Only the difference in tree height was not significant $(\mathrm{p}>0.05)$. The differences in mangrove forest structure may be due to differences in climate, topography and geomorphology, etc. among study sites $[1,2,5]$. In this paper we studied the relationship between the stem diameter, tree height, biomass and basal area and the climate.

The pair comparisons indicated that the differences in stem diameter, biomass and basal area between Dong Rui and Lach Sung estuary, and between Xuan Thuy national park and Lach Sung estuary were also significant $(p<0.05)$ (Table 3$)$. The differences in the mangrove forest structure could be caused by the differences in climatic condition. However, other environmental conditions such as soil, substrate and tidal, etc. could be other factors affecting the mangrove forest structure $[1,2,5]$.

\subsection{Relationship betweem climate condition and mangrove forest structure}

\subsubsection{Relationship betweem mangrove forest structure and temperature}

The relationships between the structural characteristics of mangrove forest and temperature are shown in Figure 2. Stem diameter, tree height, basal area and biomass had positive linear relationship with annual average temperature and January average temperature. Stem diameter, tree height, basal area and biomass increase if annual average temperature and January average temperature increase. Our result in this study was also consistent with the findings of MendezAlonzo (2008), Pool (1977) and Novitzky (2010) [13, 14, 15].

The goodness of fit of all the regression equations to measured data was assessed by considering regression coefficient $\left(\mathrm{R}^{2}\right)$ and F-test. A consistently low positive regression coefficient of less than 0.66 was found among the variables stem diameter, tree height, basal area, biomass, annual average temperature and January average temperature). The highest regression coefficient was found between biomass and annual average temperature $\left(R^{2}=0.66\right)$ and the lowest was found between tree high and January average temperature $\left(R^{2}=0.35\right)$. The rather low correlation coefficients found in this study could be explained by the fact that we only consider the temperature condition, while other environmental factors such as soil, substrate, tidal, etc. could also affect mangrove forest $[1,2,5]$. Although the correlation coefficients of the regression equations were low, the F-test result showed that all models were statistically significant at the p-value of 0.05 . It means that the models fit measured data well. 

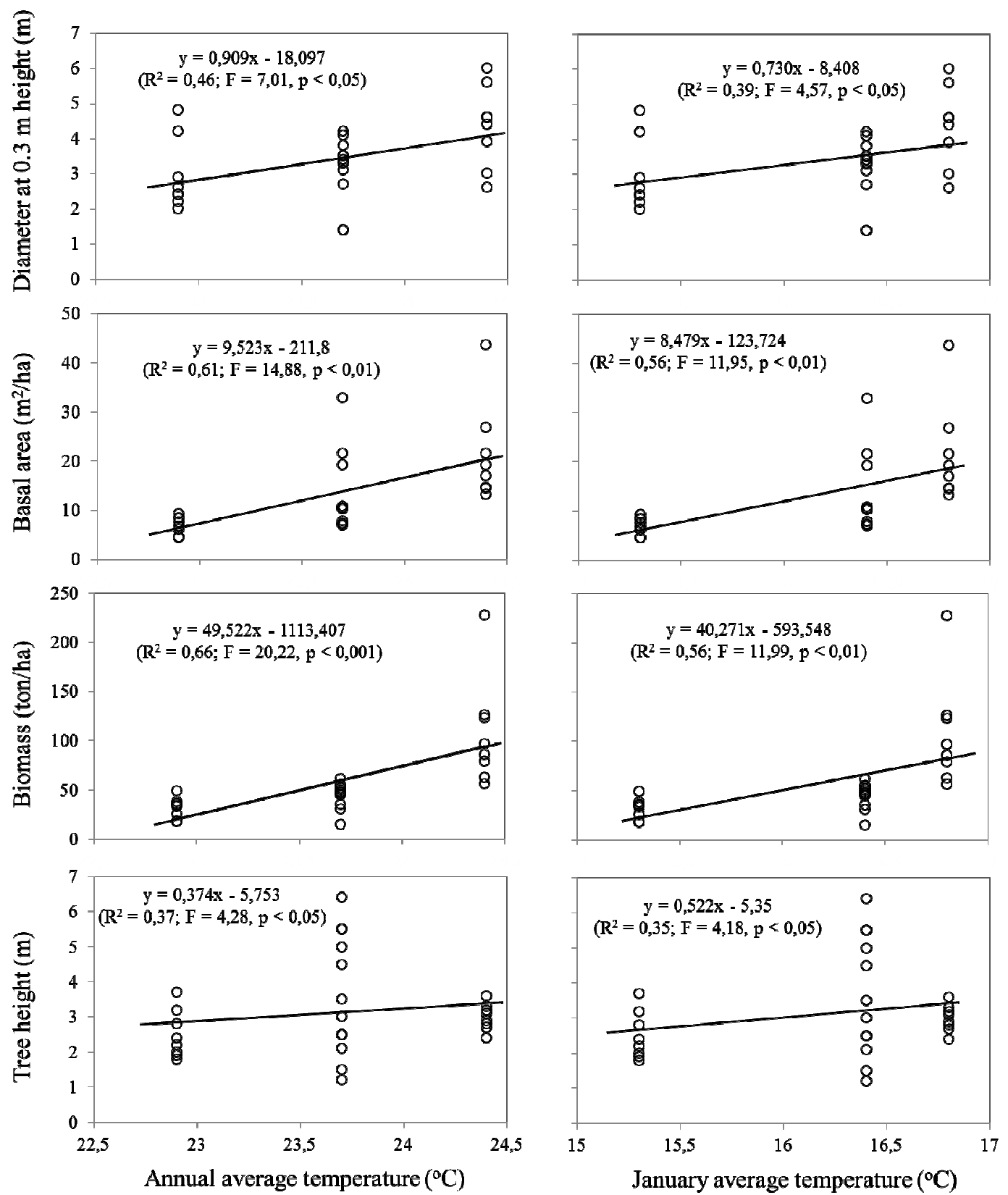

Figure 2. Relationship betweem mangrove forest structure and temperature on northern coast of Vietnam.

\subsubsection{Relationship betweem mangrove forest structure and rainfall}

The relationships between the structural characteristics of mangrove forest and annual average rainfall are shown in Figure 3. Unlike relationship with temperature, stem diameter, tree height, basal area and biomass had negative linear relationship with annual average rainfall. Stem diameter, tree height, basal area and biomass decrease if annual average rainfall increases.

A consistently low regression coefficient was also found among variables stem diameter, tree height, basal area and biomass, and annual average rainfall. The highest regression 
coefficient was found between basal area and annual average rainfall $\left(\mathrm{R}^{2}=0.59\right)$ and the lowest was found between biomass and annual average rainfall $\left(\mathrm{R}^{2}=0.29\right)$. These low correlation coefficients could be also explained by the fact that we only consider the rainfall condition, while other environmental factors such as soil, substrate, tidal ... could also affect mangrove forest $[1,2,5]$. Moreover, the F-test result also indicated that all models were statistically significant at the p-value of 0.05 .
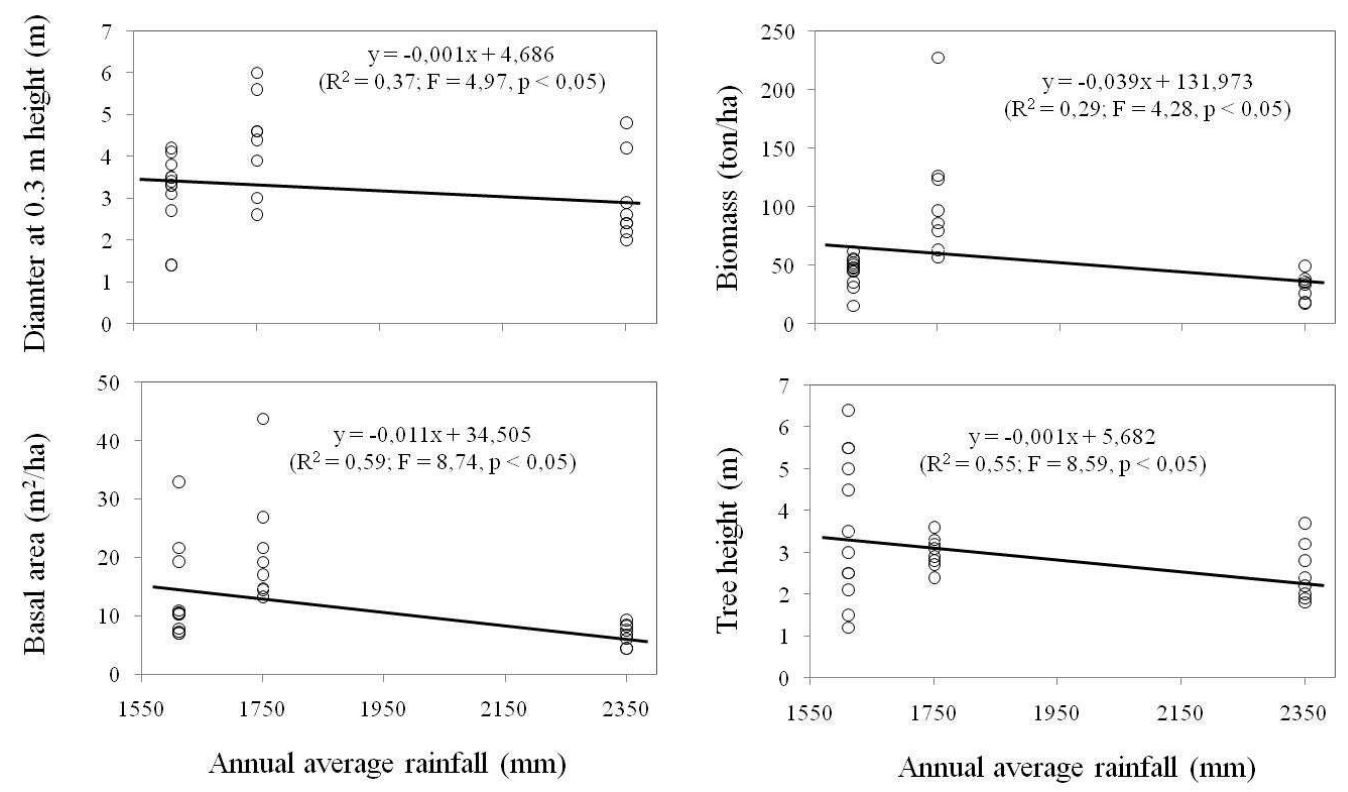

Figure 3. Relationship betweem mangrove forest structure and rainfall on northern coast of Vietnam.

The results of both relationship between mangrove forest structure and temperature, and relationship betweem mangrove forest structure and rainfall could countribute to construction of multiple linear regression models of temperature, rainfall and other factors for predicting the change of mangrove ecosystems.

\section{CONCLUSION}

The differences in mangrove forest structure (stem diameter. biomass and basal area), climate condition (temperature and rainfall) among study sites were significant ( $p<0.05)$. Stem diameter, tree height, basal area and biomass had positive linear relationship with annual average temperature and January average temperature, and negative linear relationship with annual rainfall.

The study results also indicated that there were a weak but significant relationship between stem diameter and annual average temperature $\left(\mathrm{R}^{2}=0.46, \mathrm{p}<0.05\right)$; stem diameter and January average temperature $\left(\mathrm{R}^{2}=0.39, \mathrm{p}<0.05\right)$; stem diameter and annual average rainfall $\left(\mathrm{R}^{2}=0.37, \mathrm{p}<0.05\right)$; tree height and annual average temperature $\left(\mathrm{R}^{2}=0.37, \mathrm{p}<0.05\right)$; tree height and January average temperature $\left(R^{2}=0.35, p<0.05\right)$; tree height and annual average rainfall $\left(R^{2}=0.55, p<0.05\right)$; basal area and annual average temperature $\left(\mathrm{R}^{2}=0.61, \mathrm{p}<0.01\right)$; basal area and January average temperature $\left(\mathrm{R}^{2}=0.56, \mathrm{p}<0.01\right)$; basal area and annual average rainfall $\left(\mathrm{R}^{2}=0.59, \mathrm{p}<0.05\right)$; biomass and annual average temperature $\left(\mathrm{R}^{2}=0.66, \mathrm{p}<0.01\right)$; biomass and January average temperature $\left(R^{2}=0.56, p<0.01\right)$; biomass and annual average rainfall $\left(R^{2}=0.29, p<0.05\right)$. 


\section{REFERENCES}

1. Phan Nguyen Hong - Vietnam mangrove ecology, $\mathrm{PhD}$ thesis, Hanoi National University of Education, Hanoi (1991) (in Vietnamese).

2. Phan Nguyen Hong and Hoang Thi San - Mangroves of Vietnam, IUCN, Bangkok, Thailand (1993).

3. Kauffman J.B. and Donato D.C. - Protocols for the measurement, monitoring and reporting of structure, biomass and carbon stocks in mangrove forests, CIFOR Working Paper 86, Bogor, Indonesia (2012).

4. Nagelkerken I., Roberts C.M., Van der Velde G., Dorenbosch M., Van Riel M.C., Cocheret de la Mornière E., and Nienhuis P.H. - How important are mangroves and seagrass beds for coral-reef fish? The nursery hypothesis tested on an island scale, Marine Ecology Progress Series 244 (2002) 299-305.

5. Nguyen Hoang Tri - Mangrove ecology, Agricultural publishing house, Hanoi (1999) (in Vietnamese).

6. Pham Hong Tinh and Mai Sy Tuan - Allometric relationship and biomass partition of Kandelia obovata Liu \& Yong planted in Nam Dinh Province, Journal of Sciences of Hanoi National University of Education 58 (9) (2013) 91-103.

7. Ministry of Natural Resources and Environment - Climate change scenarios and sea level rise for Vietnam, Hanoi (2012) (in Vietnamese).

8. Nguyen Nghia Thin - Methods for studying botany, Vietnam National University-Hanoi Publishing House (2008) (in Vietnamese).

9. Komiyama Akira - Common allometric equations for estimating the tree weight of mangroves, Journal of Tropical Ecology 21 (2005) 471-477.

10. Blasco F. - Mangroves as indicators of coastal change, Catena 27 (1996) 167-178.

11. Crow Edwin L., France A. Davis and Margaret W. Maxfield - Statistics Manual, Mineaola, New York: Dover Publications, Inc. (1960).

12. Dao Huu Ho - Probability and Statistical, Vietnam National University-Hanoi Publishing House (2007) (in Vietnamese).

13. Medez-Alonzo Rodrigo - Latitudinal variation in leaf and tree traits of the mangrove Avicennia germinans (Avicenniaceae) in the Central Region of the Gulf of Mexico, Biotropica 40 (4) (2008) 449-456.

14. Novitzky Peter - Analysis of mangrove structure and latitudinal relationships on the Gulf Coast of peninsular Florida, Graduate School Theses and Dissertations, University of South Florida (2010).

15. Pool Douglas - Structure of mangrove forests in Florida, Puerto Rico, Mexico, and Costa Rica, Biotropica 9 (3) (1977) 195-212. 